\title{
The Water Quality and Trophic Status of Koto Panjang Reservoir, Indonesia
}

\author{
Dina Muthmainnah ${ }^{\text {a,b,*, }}$, Aroef Hukmanan Rais ${ }^{\text {a }}$ \\ ${ }^{a}$ Research Institute for Inland Fisheries and Extension - Ministry of Marine Affairs and Fisheries \\ ${ }^{\mathrm{b}}$ Inland Fishery Resources Development and Management Department (IFRDMD) - SEAFDEC \\ * e-mail: dina.muthmainnah@kkp.go.id
}

Received 15 October $2021 \quad$ Accepted 20 December 2021

Published 30 December 2021

DOI: 10.51264/inajl.v2i2.19

\begin{abstract}
Koto Panjang Reservoir is one of the hydroelectric power plants in Indonesia, located in Kampar Regency, Riau Province. This paper aims to determine the water quality and tropic status of the Koto Panjang Reservoir. The research was carried out along the Koto Panjang Reservoir, covering the floating net cages area, inlet, outlet, and the center of the reservoir. Water samples were collected twice a year, February and September 2017. The results showed that the water quality of Koto Panjang reservoir is still within the tolerance range for the aquatic organisms' life, including fish. Based on the TSI analysis, the Koto Panjang Reservoir throphic status was categorized as eutrophic to heavy eutrophic. This study recommends that relocating floating net cages is necessary so that the nutrient load will not only be concentrated in one location. The efficiency of using the feed for floating net cages could minimize the waste.
\end{abstract}

Keywords: Trophic status, TSI, Koto Panjang Reservoir, water quality

\section{INTRODUCTION}

A reservoir is a man-made lake that built for a variety of purposes including electricity power, irrigation, flood control, source of drinking water, tourism, and fishery industry (Cowx, 2002). Unfortunately, valuable resources such as water quality, fish diversity, and wildlife are not given attention to during the construction. Until 2018, there was 254 reservoir built and operated in Indonesia. Koto Panjang Reservoir was built in 1992 and started operation in 1996, located in Kampar Regency, Riau Province. Besides being the power plant, this reservoir also has been utilized for fisheries and aquaculture by local people. After the reservoir was built, the local people utilized the water body for culturing the fish using the floating net cage surrounding the reservoir. The number of cages was 196 plots in 2003 (Nur, 2006), 513 plots in 2006, 900 plots in 2009 (Siagian, 2010), and 1,100 plots in 2013 (Simarmata et al., 2013).
According to Kartamihardja (1995), the mass death of fish cultivated in reservoirs and lakes is due to the exceeding carrying capacity of the reservoir. Based on Hartoto \& Ridwansyah (2002), the mass mortality of caged fish directly occurs during deteriorating of water quality and the emergence of algal blooms. It is caused by the lack of attention to the principles of fish farming technology and the lack of awareness of the carrying capacity of the waters (Nastiti et al., 2001). Koswara (1999) stated that the increase of the phytoplankton population caused the respiration rate to increased at night, resulting in oxygen deficiency and increased $\mathrm{CO}_{2}$ above the tolerance threshold for fish needs.

The health status of Koto Panjang Reservoir needs to be monitored to keep maintaining the sustainability of the fish and wildlife resources. This paper aims to determine the water quality and tropic status of the Koto Panjang Reservoir. It could give the information before deciding the effective way for water environment and fishery management. 


\section{METHODS}

\section{Study area}

The Koto Panjang PLTA Reservoir is located in Riau Province and West Sumatra Province (N: $0^{\circ} 30^{\prime} 44^{\prime \prime}-\mathrm{S}: 0^{\circ} 04^{\prime} 41^{\prime \prime}$ and W $100^{\circ} 08^{\prime} 31^{\prime \prime}-100^{\circ}$ $\left.54^{\prime} 25^{\prime \prime}\right)$. It has an area of 12,400 ha, and the maximum water level is $85 \mathrm{~m}$ above sea level (a.s.l).

\section{Water Quality Monitoring}

The research was carried out along the Koto Panjang Reservoir, covering the floating net cages area, inlet, outlet, and the center of the reservoir. Water samples were collected twice a year, February and September 2017. The time was chosen to represent the water level decreased and increased since it was the end and the beginning of the rainy season, respectively. The map of water quality monitoring sites is shown in Figure 1 . The samples were collected in seven stations (Table 1).

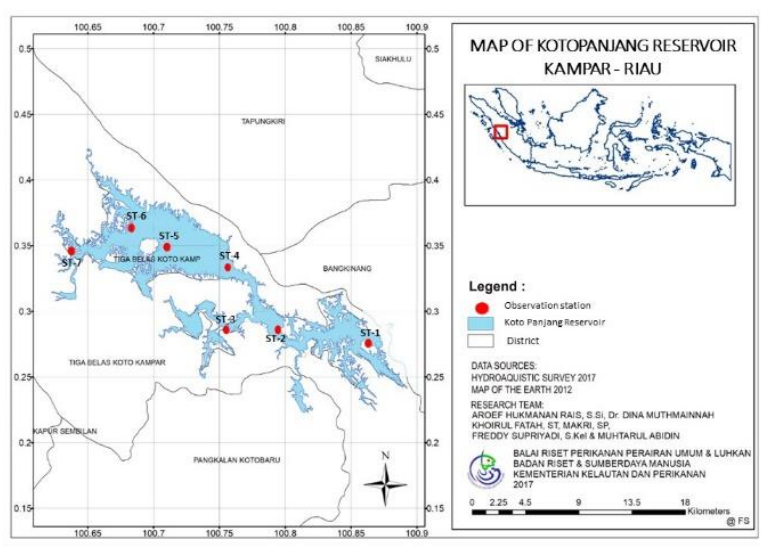

Figure 1. Map of Koto Panjang Reservoir

Table 1. Description of sampling station

\begin{tabular}{|c|c|}
\hline Station & Description \\
\hline 1 & $\begin{array}{l}\text { Kotomasjid, was an outlet of reservoir, } \\
\text { located in outdoor of reservoir. }\end{array}$ \\
\hline 2 & $\begin{array}{l}\text { Tanjung Alas was the center of fish net } \\
\text { cages. }\end{array}$ \\
\hline 3 & $\begin{array}{l}\text { Batubasurat, was the branch of reservoir } \\
\text { that still inundated, and uutilized for the } \\
\text { captured activities. }\end{array}$ \\
\hline 4 & $\begin{array}{l}\text { Jembatan Gulamo, was located in Tanjung } \\
\text { Alas Village, and uutilized for the capture } \\
\text { activities. }\end{array}$ \\
\hline 5 & $\begin{array}{l}\text { Pongkai, was for captured activities with } \\
\text { variety of fishing gears. Closed to oil palm } \\
\text { plantations. }\end{array}$ \\
\hline 6 & $\begin{array}{l}\text { Binamang, was in the Binamang Village, } \\
\text { shallow waters, and closed to plantation } \\
\text { area. }\end{array}$ \\
\hline 7 & $\begin{array}{l}\text { Muara Takus, was the inlet area with } \\
\text { shallow waters. }\end{array}$ \\
\hline
\end{tabular}

The water sample was carried out by water sampler on the surface ( $\pm 1 \mathrm{~m}$ depth), and bottom layers. Several physical parameters such as temperature, $\mathrm{pH}$ and dissolved oxygen were analyzed in-situ by using thermometer, $\mathrm{pH}$ meter and DO meter, respectively. While the other parameters were analyzed in the laboratory. Measurement and analysis of water samples were carried out in the Research Institute for Inland Fisheries and Extension Laboratory, referred to APHA (2017). Water quality parameters shown in Table 2.

Table 2. Measured water parameters during the study.

\begin{tabular}{|c|c|c|c|}
\hline No & Parameter & Unit & Method/Instrument \\
\hline 1. & Temperature & ${ }^{\circ} \mathrm{C}$ & Termometer \\
\hline 3. & Total Dissolve Solid & $\mathrm{mgL}^{-1}$ & TDS meter \\
\hline 4. & Conductivity & $\mu$ hos.cm ${ }^{-1}$ & Conductivity meter \\
\hline 6. & Transparency & $\mathrm{cm}$ & Secchi Disk \\
\hline 7. & Total Suspended Solids & $\mathrm{mgL}^{-1}$ & Gravimetric analysis \\
\hline 8. & $\mathrm{pH}$ & Unit & $\mathrm{pH}$ meter \\
\hline 9. & Dissolved Oxygen & $\mathrm{mgL}^{-1}$ & DO meter \\
\hline 11. & Carbon Dioxide & $\mathrm{mgL}^{-1}$ & Acid-base \\
\hline 12. & Alkalinity & $\mathrm{mgL}^{-1}$ & $\begin{array}{l}\text { Titration } / \mathrm{NaOH} \\
\text { Bromocresol green } \\
\text { indicator titration }\end{array}$ \\
\hline 13. & Hardness & $\mathrm{mgL}^{-1}$ & Titration EDTA \\
\hline 14. & Total Phosporus & $\mathrm{mgL}^{-1}$ & $\begin{array}{l}\text { Spectrophotometer } \\
\text { ascorbate acid with } \\
\text { destruction }\end{array}$ \\
\hline 15. & Ortho-Phosphate & $\mathrm{mgL}^{-1}$ & $\begin{array}{l}\text { Spectrophotometer } \\
\text { ascorbate acid }\end{array}$ \\
\hline 16. & Ammonia & $\mathrm{mgL}^{-1}$ & $\begin{array}{l}\text { Spectrophotometer } \\
\text { Phenate }\end{array}$ \\
\hline 17. & Nitrite & $\mathrm{mgL}^{-1}$ & $\begin{array}{l}\text { Spectrophotometer } \\
\text { Sulfanilamide }\end{array}$ \\
\hline 18. & Nitrate & $\mathrm{mgL}^{-1}$ & $\begin{array}{l}\text { Spectrophotometer } \\
\text { Brucine Sulfate }\end{array}$ \\
\hline 19. & Chlorophyll-a & $\mu \mathrm{g} . \mathrm{L}^{-1}$ & Spectrophotometric \\
\hline
\end{tabular}

The water body's Trophic Status Index (TSI) can be assessed using phosphorus, that representing of the limiting nutrients in the water body. Methods for classifying trophic states are based on the foundational work of Carlson from 1977:

where:

$$
T S I=\frac{\left(T S I_{S D}+T S I_{T P}+T S I_{C h l}\right)}{3}
$$

$$
\begin{aligned}
T S I_{S D} & =60-14.41^{*} \mathrm{Ln}(\mathrm{SD}), \mathrm{SD} \text { is transparency in } \\
& \text { meters } \\
T S I_{T P} & =4.15+14.42 * \mathrm{Ln}(\mathrm{TP}), \mathrm{TP} \text { is Total } \\
& \text { Phosphor }(\mathrm{mg} / \mathrm{l}) \\
T S I_{C h l} & =30.6+9.81^{*} \mathrm{Ln}(\mathrm{Chl}), \mathrm{Chl} \text { is Chlorophyll- } \\
& \text { a concentration }(\mu \mathrm{g} / \mathrm{l}) .
\end{aligned}
$$

Based on the values of TSI, the lakes are classified as oligotrophic (low productive), mesotrophic (moderately productive), and eutrophic (highly productive). The range of Carlson's trophic state index values and the lake classification are shownin Table 3. 
Table 3. Carlson's trophic state index values and classification of lakes (Prashad, 2012)

\begin{tabular}{|c|c|c|}
\hline $\begin{array}{c}\text { TSI } \\
\text { values }\end{array}$ & Trophic status & Indicators \\
\hline$<30$ & Oligotrophic & $\begin{array}{l}\text { Clear water, oxygen throughout } \\
\text { the year in the hypolimnion }\end{array}$ \\
\hline $30-40$ & Oligotrophic & $\begin{array}{l}\text { A lake will still exhibit } \\
\text { oligotrophy, but some shallower } \\
\text { lakes may become anoxic during } \\
\text { the summer }\end{array}$ \\
\hline $40-50$ & Mesotrophic & $\begin{array}{lcr}\text { Water } & \text { moderately } & \text { clear; } \\
\text { increasing } & \text { probability } & \text { of } \\
\text { hypolimnetic } & \text { anoxia } & \text { during } \\
\text { summer } & & \end{array}$ \\
\hline $50-60$ & Low Eutrophic & $\begin{array}{l}\text { Lower boundary of classical } \\
\text { eutrophic: decreased transparency, } \\
\text { warm-water fisheries only }\end{array}$ \\
\hline $60-70$ & $\begin{array}{l}\text { Medium } \\
\text { Eutrophic }\end{array}$ & $\begin{array}{l}\text { Blue-green algae dominate, alga } \\
\text { scums and macrophyte problems }\end{array}$ \\
\hline $70-80$ & $\begin{array}{l}\text { Heavy } \\
\text { Eutrophic }\end{array}$ & $\begin{array}{l}\text { Heavy alga blooms possible } \\
\text { throughout the summer, often } \\
\text { hypereutrophic }\end{array}$ \\
\hline$>80$ & Hypereutrophic & $\begin{array}{l}\text { Alga scums, few macrophytes, } \\
\text { summer fish kills }\end{array}$ \\
\hline
\end{tabular}

\section{Data analysis}

Data analysis was performed using R software 4.1.0 version. The relationship between water quality and productivity parameters was analyzed using Principal Component Analysis (PCA) of 'ggfortify' and 'factoextra' packages (Kassambara \& Mundt, 2016), then it was showed as a biplot image. Principal Component Analysis (PCA) is an important step to avoid the independent variables multicollinearity. The dependent variable was chlorophyll, Total Phosphor, and ortho-phosphate.

\section{RESULTS AND DISCUSSION \\ Waters Environmental Condition}

The Koto Panjang finished its construction in 2000 , and it is surrounded by eight villages and around 5000 households (Kamiri \& Taifur, 2013). At the first construction of the reservoir, the water depth was around 78 - 85 meters, and 96 meters height at the dam gate (Simarmata et al., 2013). Figure 2 shows the result of a study in 2017 for bathymetric analysis by using hydroacoustic equipment. The average water depth was 17.5 meters, with a maximum water depth in 42 meters. It showed that water level decreased because of the accumulation of sedimentation. The natural siltation process occured due to human activities in the upstream area, such as logging, rice fields, and plantations that caused erosion and the soil then carried by water to the lowest site (Suprayogi \& Bochari, 2014).

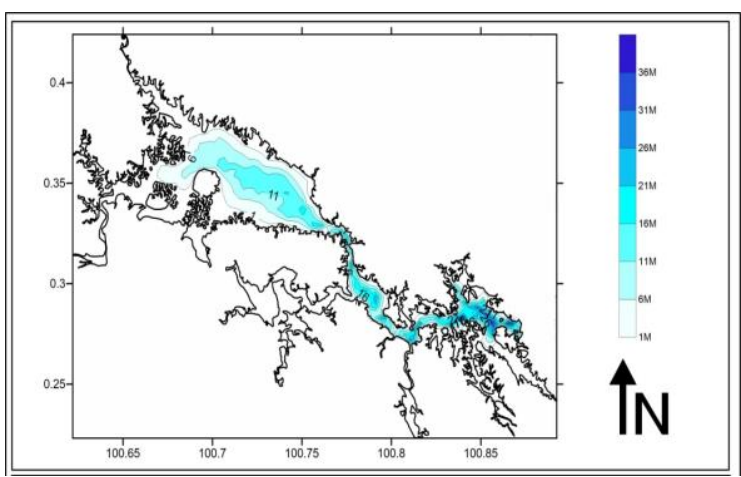

Figure 2. Bathymetric map of Koto Panjang Reservoir.

The stratification of temperature is shown in Figure 3. Every five to seven meters, the temperature will decrease about $2^{\circ} \mathrm{C}$. However, the temperature differences were within normal values and are still good for the growth and metabolism of aquatic organisms. The average water temperature for aquatic life was $26-32{ }^{\circ} \mathrm{C}$, which ensures the metabolism, oxygen production, and degradation of toxic matter running well (Madden et al, 2013).

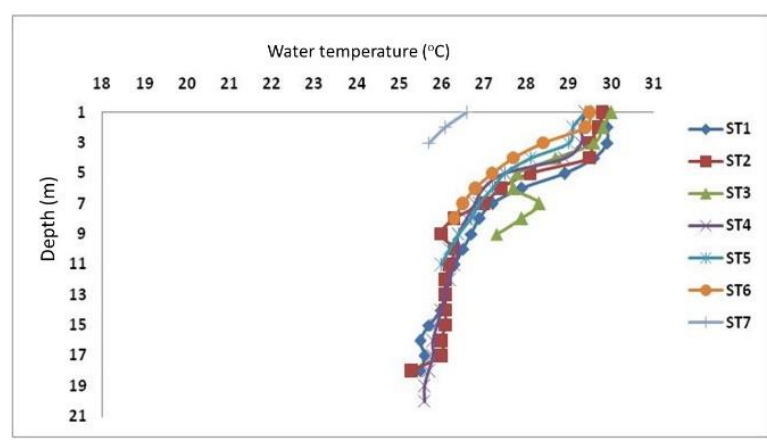

Figure 3. The vertical profile of water temperature at all sampling stations

Total dissolved solids (TDS) in September was more than in February, with a range in 10.5-24.9 $\mathrm{mg} / \mathrm{l}$ (Figure $4 \mathrm{a}$ ). The TDS value is influenced by sediment, and particles that are rinsed and enter the waters. The fluctuation of conductivity is shown in Figure 4b, which in September was higher than February due to rainwater. The conductivity in the upstream reservoir was higher since it is closer to the inlet of the Kampar River. Figure $4 \mathrm{c}$ shows the result of the study that the highest transparency found at station 4. This station was in the middle part of the reservoir, quite deep, and not much activity around it. The lowest value found at station 7 since it was a shallow area and the inlet of the reservoir. The condition at station 7 made the sediment was easy to mix and lower transparency/. The transparency value is influenced by weather conditions, measurement time, turbidity, and suspended solids. 


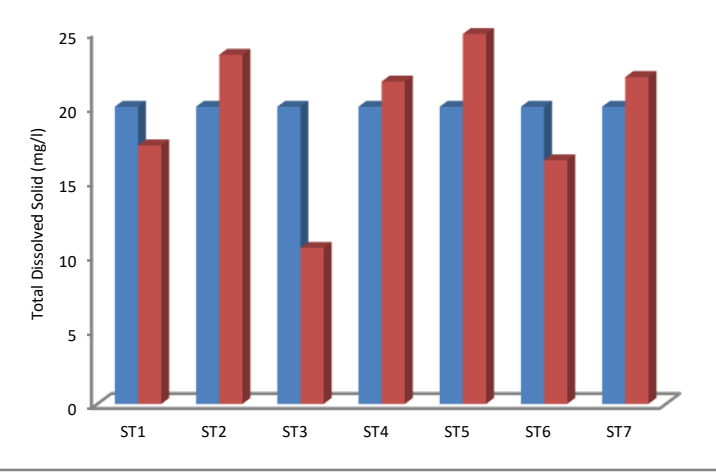

a. Total Dissolved Solids

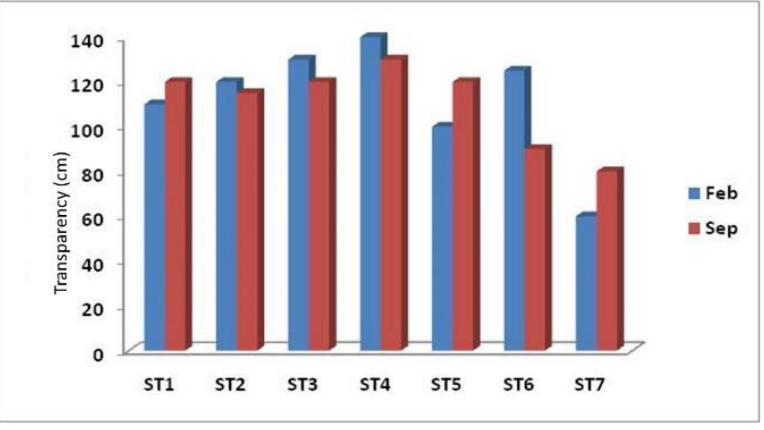

c. Transparency

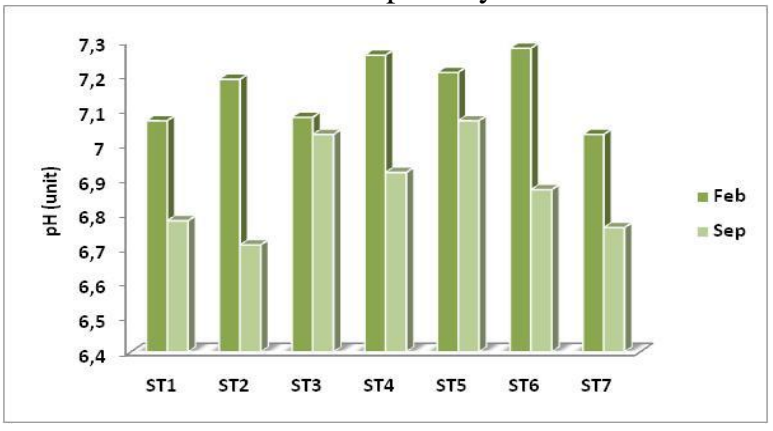

e. $\mathrm{pH}$

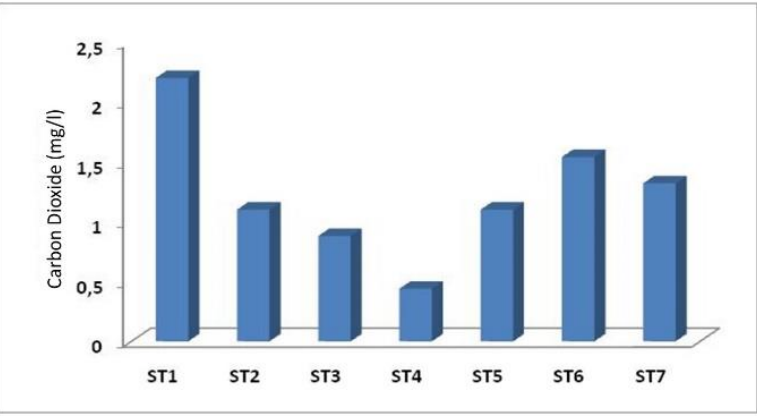

g. Carbon Dioxide

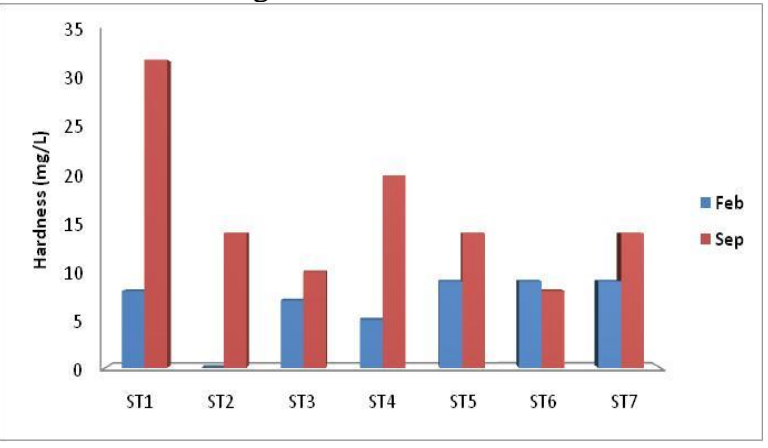

I. Hardness

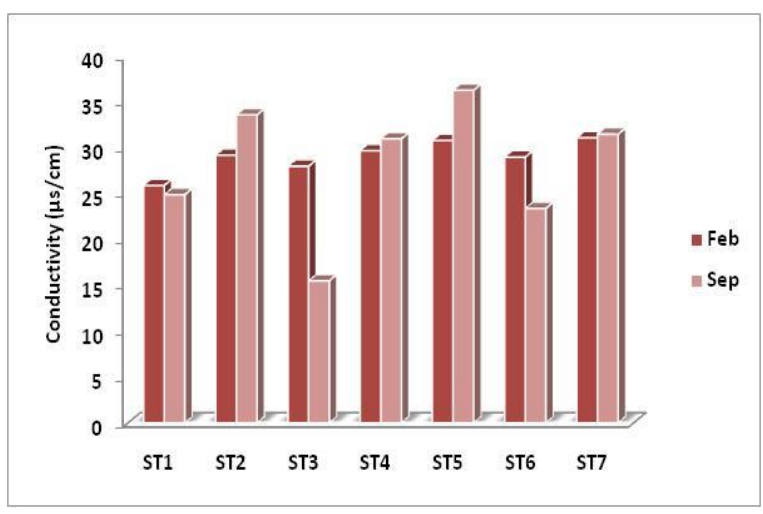

b. Conductivity

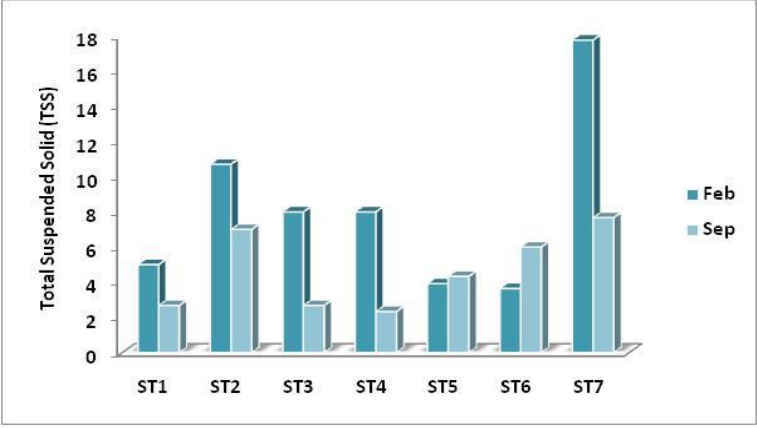

d. Total Suspended Solids

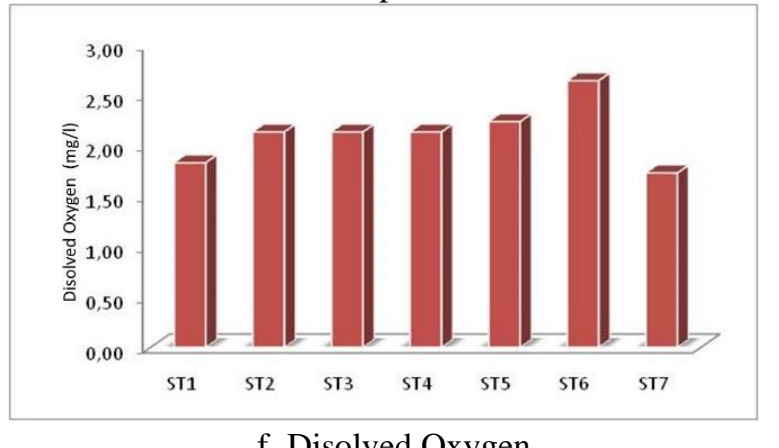

f. Disolved Oxygen

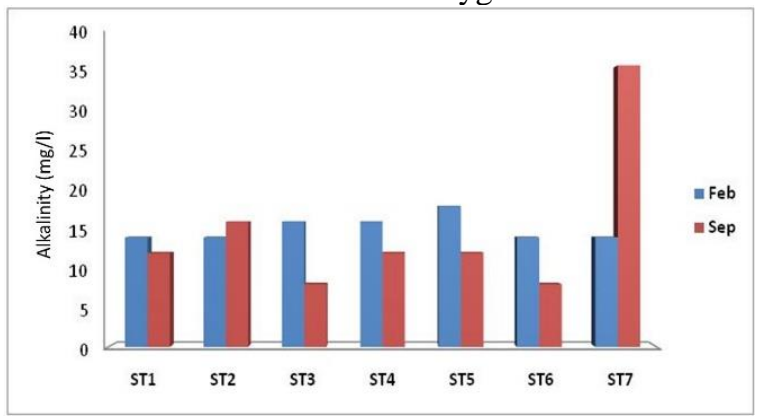

h. Alkalinity

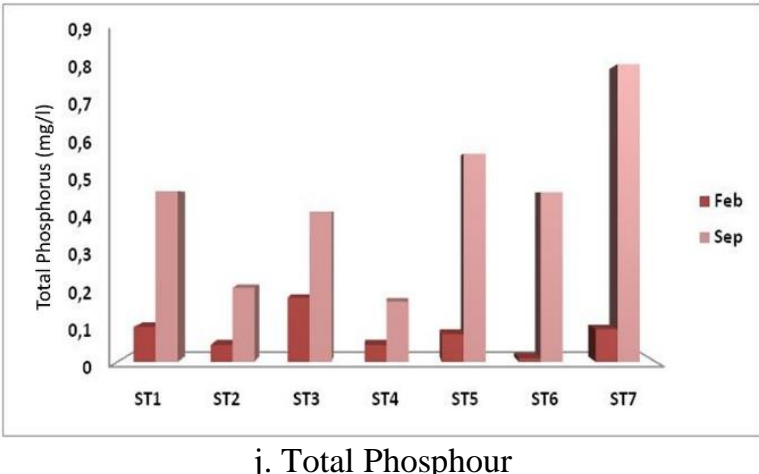

j. Total Phosphour 


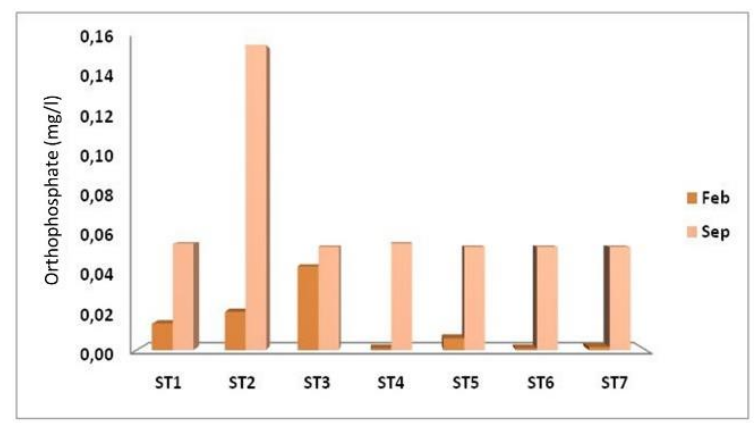

k. Orthophosphate

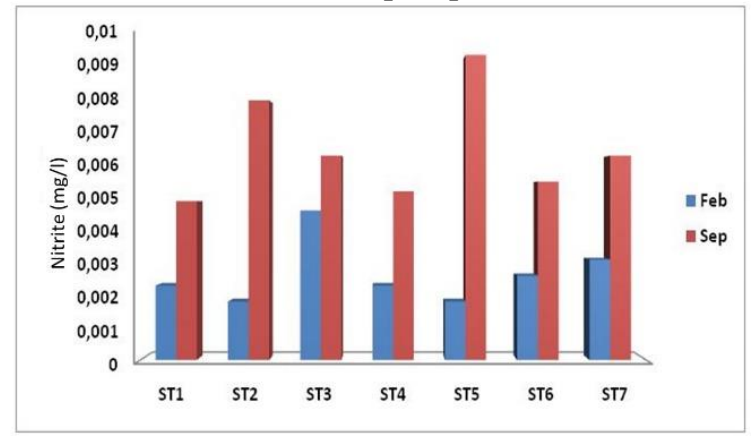

m. Nitrite

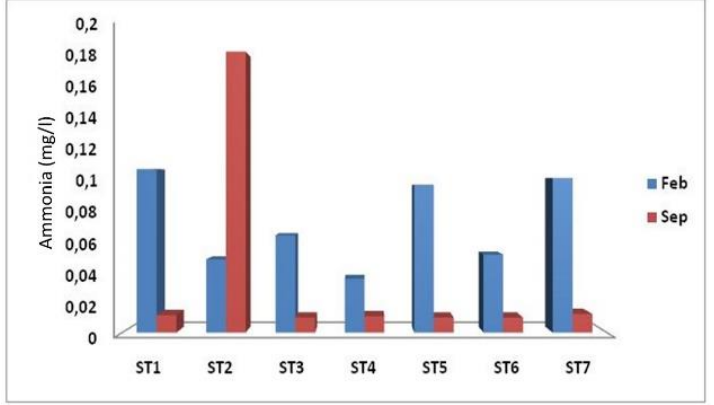

1. Ammonia

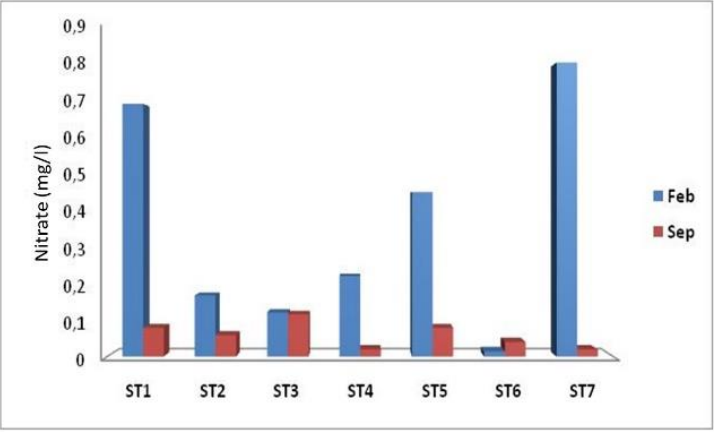

n. Nitrate

Figure 4. Water quality parameters at all sampling stations during the study period: a. Total dissolved solids; b. Conductivity; c. Transparency; d. Total suspended solids; e. pH; f. Disolved Oxygen; g. Carbon dioxide; h. Alkalinity; i. Hardness; j. Total Phosphate; k. Ortho-phosphate; 1. Ammonia; m. Nitrite; n. Nitrate

The fluctuation correlation on total suspended solids, conductivity, and transparency value was strongly adequate. Consequently, the mineral dissolved in sediment was suspended on the water flows, rock erosion on natural and anthropogenic factors (Olasehinde \& Abeke, 2012). During the flooding, the transparency is strongly influenced by suspended and dissolved organic/inorganic materials, as well as the abundance of plankton and other microorganisms (Beaver et al., 2013).

Total suspended solids (TSS) value is the biophysical status of inland waters, that describe the environmental health due to degradation impact of the water bodies such as sedimentation by rock scraping and change of the landform in the upstream (Effendie, 2003). The TSS value at the sampling site is shownin Figure 4d. The higher TSS value is in February because of the dry season with a high intensity of water surface movement. The higher value was at station 7 since the water level was lower, and the sedimentation was thicker due to the incoming material rock from the upstream. The dry season resulted in the decrease of water volume in the reservoir, rise in the alga abundance, and extreme movement of the water surface, thereby increasing suspended solid materials agitation (Brasil et al, 2015).

Figure 4e showed the $\mathrm{pH}$ in February was higher than in September due to the dry season.
The $\mathrm{pH}$ value in these stations was in a good range for fish life, and there was no indication of drastically dropping at each sampling station. The $\mathrm{pH}$ is still ideal for supporting the life and breeding of aquatic organisms in accordance with Boyd (1979); the $\mathrm{pH}$ range at 6-9 is an ideal for fisheries production. Based on water quality standards for class I, the $\mathrm{pH}$ of water is ranged in 6-9.

Dissolved oxygen is shown in Figure 4f. The oxygen concentration was relatively low because the pollutants i.e. residual of fish feed, fuel, and fertilizer were increased. The oxygen value decreased caused by the decomposition of the waste material by the bacterial organism. The bacterial decomposed the toxic substance to the natural matter such as nitrogen (Mahdavi et al, 2015). The carbon dioxide observed at each sampling location is shown in Figure $4 \mathrm{~g}$. The highest carbon dioxide was found at station 1 , with a high number of floating net cages. A high concentration of carbon dioxide indicated the poor site due to a large amount of respiration of algae organism. The respiration of algae can be reducing the oxygen level and increase the carbon dioxide concentration in the water bodies.

The fluctuation value of alkalinity and hardness concentration in the Koto Panjang Reservoir is shownin Figure $4 \mathrm{~g}$ and $4 \mathrm{i}$. The alkalinity value in February was relatively 
distributed in each sampling station. Meanwhile, fluctuations occurred in September, especially at station 7 . The value increased since the water flows from upstream brought the sediment and rock scrap that contain the mineral such as carbonates, bicarbonates, hydroxides, phosphate, calcium, magnesium, and other compounds comes into the reservoir (Bhatanagar \& Devi, 2013). During September, the hardness value fluctuated, with the highest value being in station 1. Boyd et al. (2016) stated that the waters with the accumulation of the limestone as the major sources of alkalinity and hardness components will have the high hardness. Station 1 was the dam gate and also the downstream of the reservoir, so water flows made the sediment trapped in this station.

Phosphor is a limiting compound used to grow and develop aquatic organisms such as plankton (Hutabarat, 2001). Total phosphor material and its free form (orthophosphate) describe the essential nutrients for the growth of living things, especially for aquatic biota. Fluctuations in total phosphor and ortho-phosphate values in the Koto Panjang reservoir are shown in Figure $4 \mathrm{j}$ and $4 \mathrm{k}$. The total phosphour concentration in February is lower than in September. In September, when the rainy season, concentration increases, rock-eroded material enters the waters as a source of phosphor. The highest concentrationis found at station 7, caused by the input of water from the upstream of the Kampar River to the inlet of the Koto Panjang reservoir. The phosphor concentration were lower near the reservoir gate because of the flushing process or the water discharge from the reservoir into the Kampar River through the dam gate. The rinsing causes the phosphor concentration going to decrease. Orthophosphate value is a simple phosphor material in the waters. The orthophosphate is easily used by aquatic organisms. In February, the concentration of Orthophosphate was high at station 3 because of feed remained. In September, the highest value found at Station 2 due to the higher residual $P$ from feed waste that had not been rinsed into the Kampar River.

A fluctuation of ammonia in the waters is shown in Figure 41. In February, the enormous process of organism degradation causes the instability of aerobic microbes in the waters. Meanwhile, the highest value found at Station 2 in September due to the incomplete rinsing process, leaving an excessive ammonia concentration in the Koto Panjang Reservoir. Nitrite is intermediate form of $\mathrm{N}$ between ammonia and nitrate and between nitrate and nitrogen gas (denitrification) (Effendie, 2003). Its toxic nature and transitional molecule make nitrite found in small concentrations. The fluctuations in the nitrite value is shown in Figure 4m. In September, the highest nitrite concentration found at station 3; this could be due to the denitrification process around station 3. In September, the nitrite value was increased at station 5. Overall, the nitrite value in the waters of the Koto Panjang reservoir was still low. The $0.06 \mathrm{mg} / \mathrm{l}$ is still suitable for the life of aquatic organisms. Nitrate is the main form of nitrogen in natural waters and it is the primary nutrient for plant and algae growth. The fluctuations in nitrate values during the study is shown in Figure 4n. In February, the nitrate concentration were very high at Station 1 near the reservoir gate and in the village of Muara Takus (ST7). The high concentration foundat station 1 that can be caused by the concentration of nutrients in a narrow location. While the high value at station 7 can be caused by material input to the organisms' needs, such as algae. In September, the nitrate value was lower than in February.

\section{Principal Components Analysis of Water Quality Parameters in Koto Panjang Reservoir.}

PCA could explain 56\% correlation of water quality parameters. The trophic level on the reservoir ecosystem was related to some key factors such as chlorophyll-a, phosphate, ammonia, and nitrate as nitrogen parameters. The chlorophyll-a value has a strong correlation to $\mathrm{pH}$ and transparency. At the same time, the chlorophyll was correlated negatively to nitrate and ammonia concentration. This condition can be occurring due to the concentration of nitrogen in the water bodies was oversaturated.

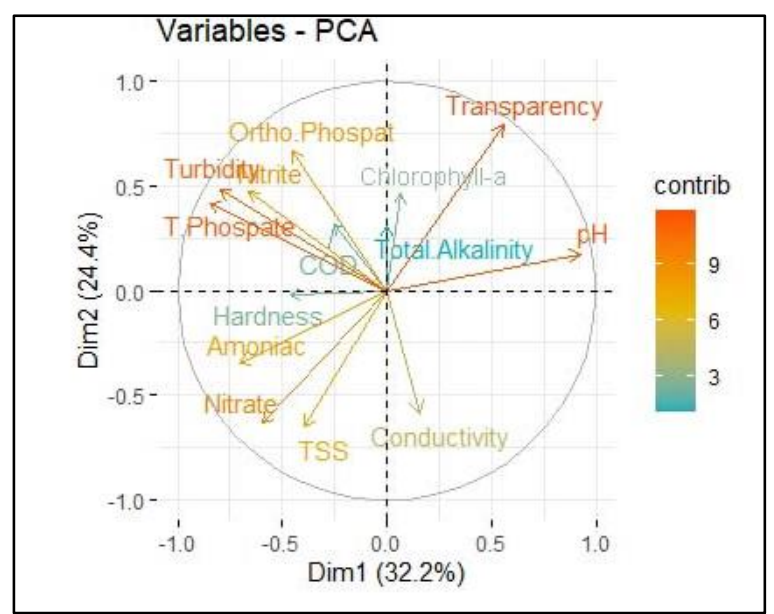

Figure 5. Principal Component Analysis (PCA) of water quality parameters in Koto Panjang Reservoir 
The oversaturated nitrogen concentration did not contribute to chlorophyll concentration optimum level (Filstrup \& Downing, 2017). Chlorophyll-a concentration was increased related strongly transparency value, which could encourage the plankton metabolism (Markad et al., 2019). Phosphate positively correlates to turbidity concentration as it impacts the accumulation of dissolved sediment. The productivity parameter has a contrary correlation to conductivity, and turbidity could increase it. The water mixing made the phosphate completely dissolve in the water (Domingues et al., 2011).

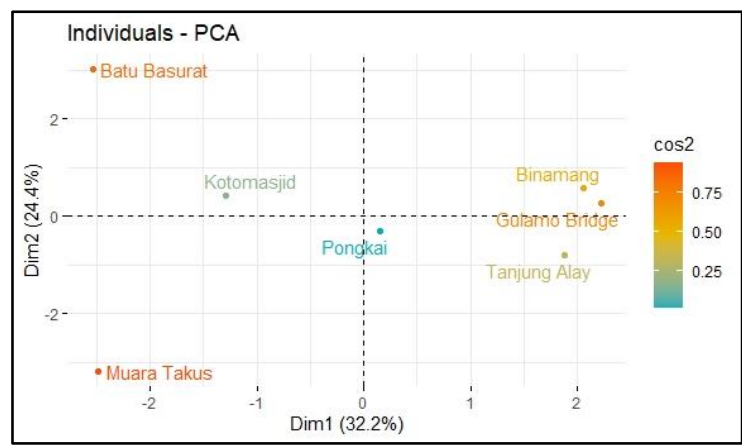

Figure 6. Principal Component Analysis in seven sampling stations of Koto Panjang Reservoir

The PCA analysis divided the sampling stations into four groups based on the basic parameters' similarity and closed distance linkage. The first group was Kotomasjid and Batubasurat, based on the lowest conductivity and the highest total phosphor. The second group was Binamang and Jembatan Gulamo, characterized by the highest $\mathrm{pH}$ value. Due to the lowest nitrite value, Tanjung Alay and Pongkai became the third group. Muara Takus became the fourth group formed by the highest nitrate, TSS, and conductivity.

\section{Determination of Trophic Status Index (TSI)}

TSI can be determined based on transparency, phosphate total, and chlorophyll parameters. TSI has described the water productivity and a threshold value in ecological vulnerability (Klipple et al., 2020). Measurement of the trophic level was carried out in two versions using data on total phosphor concentration at the surface and bottom layers. The results of the analysis of the trophic status of the Koto Panjang Reservoir are shown in Table 4.

The results of the trophic state index (TSI) showed that the tropic conditions of the Koto Panjang Reservoir have reached eutrophic values $(\mathrm{TSI}=50-60)$ to heavy eutrophic $(\mathrm{TSI}=60-70)$. Kotomasjid has come to a severe eutrophic condition since the amount of leftover feed from the cages settled at the bottom layer. The color of waters became forage-colored that characterizes its condition. It also happened in the lake with floating net cages that leftover food accumulated at the bottom of the water, affected the waters color change into dark green, as reported by Makmur et al. (2020).

Table 4. Trophic Status index (TSI) at both surface and bottom layers of water at seven sampling stations in Koto Panjang Reservoir in 2017.

\begin{tabular}{lrrrr}
\hline \multirow{2}{*}{ Station } & \multicolumn{2}{c}{ February } & \multicolumn{2}{c}{ September } \\
\cline { 2 - 5 } & surface & bottom & surface & bottom \\
\hline Kotomasjid & 62.20 & 62.82 & 63.59 & 69.64 \\
Tanjung Alay & 51.16 & 52.63 & 59.36 & 62.69 \\
Batu Basurat & 61.68 & 60.90 & 70.86 & 65.47 \\
Bridge & 55.18 & 57.97 & 60.30 & 61.24 \\
Gulamo & 59.88 & 59.45 & 58.43 & 64.05 \\
Pongkai & 49.98 & 53.28 & 61.38 & 68.37 \\
Binamang & 58.09 & 59.20 & 59.55 & 71.08 \\
Muara Takus & & & & \\
\hline
\end{tabular}

The high eutrophic status value effect the blooming aquatic plants, thus affecting the oxygen supply in the waters. Aquatic ecosystems are supported by photosynthetic organisms (e.g. macrophytes, benthic and planktonic microalgae, and cyanobacteria) that fix carbon, produce oxygen, and constitute the base of food webs. Under certain circumstances, however, the abundance of some taxa can reach levels that may cause harm to humans and other organisms (Berdalet et al., 2015). Blooming algae can cause the waters to lack oxygen in a short time, especially when there is no sun supply and cold conditions. These conditions can increase oxygen consumption in the waters and harmful organisms such as fish in cages.

The main concern in aquatic ecosystems is eutrophication, which was caused by human activities. Eutrophication will decrease the water quality (Indriani et al., 2016). Trophic status requires information on the water quality to determine water and fishery management. For Koto Panjang reservoir utilization as the capture fisheries and aquaculture area, it has to attend the feasibility of trophic status (Samuel \& Ardiansyah, 2016).

\section{General Discussion}

The parameters of dissolved oxygen, alkalinity, hardness, phosphate, nitrogen, and waters' physical parameters in Koto Panjang Reservoir were still within the tolerance range for the aquatic organisms' life, including fish. Besides power plants, various activities have taken place in Koto 
Panjang reservoir, such as aquaculture, captured fishery activity, tourism destination, and irrigation for agriculture. It showed that the local community's livelihood surrounding the reservoir depends on the condition of the lake water. The reduced area of forest cover in the catchment area in the upper site caused significant water level differences in season and rainfall fluctuation. However, the intensive economic services of floating net cages raise concerns about problems due to algae blooms and a decrease in water quality.

Based on the TSI analyses, the Koto Panjang Reservoir was categorized as eutrophic values to heavy eutrophic. This study recommends that relocating floating net cages is necessary so that the nutrient load will not only be concentrated in one location. The efficiency of using the feed for floating net cages could minimize the waste. The government should manage the growth of aquaculture by the floating cages with zoning on the reservoir catchment area to avoid the critical problem in the future.

\section{CONCLUSION}

The water quality of Koto Panjang reservoir indicated still within the tolerance range for the aquatic organisms' life, including fish. The Koto Panjang Reservoir was categorized as eutrophic values to heavy eutrophic. The highest TSI value was found in the floating cage area. The eutrophic status can alert the water bodies utilization for aquaculture that throws a lot of nutrients inside the reservoir.

\section{ACKNOWLEDGEMENTS}

The study entitled "Study of Fish Stock and Potential Resources of Koto Panjang Reservoir, Riau Province" was funded by the Ministry of Marine Affairs and Fisheries Republic of Indonesia in 2017. Authors thank the team (Khoirul Fatah, Makri, Muhtarul Abidin, and Yenni S. Mulyani) for valuable helping during the field survey, laboratory work, and map preparation.

\section{REFERENCES}

APHA. 2017. Standard Methods For the Examination of Water and Wastewater. 23rd edition.

Bhatnagar, A., and Devi, P. 2013. Water quality guidelines for the management of pond fish culture. International journal of environmental sciences, 3(6), 1980-2009.

Beaver. J.R., David. E.J., D.A. Casamatta., C.E. Tausz., Kyle. C. S., K.M. Buccier., C.E. Teacher. T.C. Rosati., A. D. Minerovic., and T. R. Renicker. 2013. Response of Phytoplankton and Zooplankton Communities in Six Reservoirs of The Midle Missouri River (USA) to Drought Condition and a Major Flood Event. Hydrobiologia. (705): 173 $189 \mathrm{p}$.

Berdalet E., Fleming L.E., Gowen R., Davidson K., Hess P., Backer L.C., Moore S.K., Hoagland O., and Enevoldsen H. 2015. Marine harmful algal blooms, human health and wellbeing: challenges and opportunities in the 21st century. J Mar Biol Assoc U.K.

Boyd, C. E., Tucker, C. S., and Somridhivej, B. 2016. Alkalinity and hardness: critical but elusive concepts in aquaculture. Journal of the World Aquaculture Society, 47(1), 6-41.

Brasil, J., Attayde, J. L., Vasconcelos, F. R., Dantas, D. D., and Huszar, V. L. 2016. Drought-induced waterlevel reduction favors cyanobacteria blooms in tropical shallow lakes. Hydrobiologia, 770(1), 145164.

Domingues, R. B., Anselmo, T. P., Barbosa, A. B., Sommer, U., and Galvão, H. M. 2011. Nutrient limitation of phytoplankton growth in the freshwater tidal zone of a turbid, Mediterranean estuary. Estuarine, Coastal and Shelf Science, 91(2), 282-297.

https://doi.org/10.1016/j.ecss.2010.10.033

Effendie, M. I. 2003. Telaah Kualitas Air Bagi Pengelolaan Sumberdaya Dan Lingkungan Perairan Jurusan Manajemen Sumberdaya Perairan. Fakultas Perikanan dan Ilmu Kelautan. IPB. Bogor. 259p. in Indonesian.

Filstrup, C. T., and Downing, J. A. 2017. Relationship of chlorophyll to phosphorus and nitrogen in nutrient-rich lakes. Inland Waters, 7(4), 385-400. https://doi.org/10.1080/20442041.2017.1375176

Hartoto, D.I. and I.Riduansyah. 2002. Perhitungan Daya Dukung Danau atau Waduk untuk Pengembangan Budidaya Ikan Dalam Keramba. Laporan Teknik Puslit. Limnologi-LIPI. Cibinong Bogor. p291-303. in Indonesian.

Indriani, W., Hutabarat, S., and A'in, C. 2016. Status trofik perairan berdasarkan nitrat, fosfat, dan klorofil-a di Waduk Jatibarang, Kota Semarang. Diponogoro Journal of Maquares, 5(4): 258-264. in Indonesian.

Kamiri, S., and Taifur.W.D. 2013. Resettlement and Development: a Survey of two Indonesia's Koto Panjang resettlement village. International Journal of Water Resources Development. Vol. 29, No.1, 35 - 49 p. DOI: 10.1080/07900627.2012.739539.

Koswara, B. 1999. Degradasi Siklikal Lingkungan Perairan dan Hubungannya dengan Indikator Penyebab Kematian Ikan pada Keramba Jaring Terapung di Waduk Saguling. Disertasi Program Pascasarjana Universitas Padjadjaran Bandung. in Indonesian.

Kartamihardja, E.S. 1995. Daya Dukung Perairan dan Pengembangan Budidaya Ikan dalam Keramba 
Jaring Apung yang Ramah Lingkungan. Prosiding Ekspose Budidaya Ikan dalam Keramba Jaring Apung yang Ramah Lingkungan. Pusat Pen. dan Pengembangan Perikanan. Hal 13-22. in Indonesian.

Kassambara, A., and Mundt, F. 2016. R package version, 2016. https://cran.microsoft.com/ snapshot/2016-11-30/web/packages/ factoextra/ factoextra.pdf).

Klippel, G., Macêdo, R. L., and Branco, C. W. 2020. Comparison of different trophic state indices applied to tropical reservoirs. Lakes \& Reservoirs: Research \& Management, 25(2), 214-229.

Madden.N., A. Lewis., and M. Davis. 2013. Thermal Effluent from The Power Sector: an Analysis of Once-Through Cooling System Impacts on Surface Water Temperature. Environment Research Letter. 8 (2013): 035006

Mahdavi, H., Prasad, V., Liu, Y., and Ulrich, A. C. 2015. In situ biodegradation of naphthenic acids in oil sands tailings pond water using indigenous algae-bacteria consortium. Bioresource Technology, 187, 97-105.

Markad, A.T., Landge, A.T., Nayak, B.B., Inamdar, A.B., and Mishra, A.K. 2019. Trophic state modeling for shallow freshwater reservoir: a new approach. Environmental Monitoring and Assessment, 191(9).

Makmur, S., Muthmainnah, D., and Subagdja. 2020. Fishery activities and environmental condition of Maninjau Lake, West Sumatra. IOP Conf. Ser.: Earth Environ. Sci. 564012025.

Nastiti, A.S., Nuronial, S., Purmamaningtyas, S.E., and Kartamihardja, E.S. 2001. Daya Dukung Perairan Waduk Jatiluhur untuk Budidaya Ikan dalam
Keramba Jaring Apung. Jurnal Pen. Per. Indonesia. Vol. 7 No. 2: 14-29. in Indonesian.

Nur, M. 2006. Evaluasi Pengelolaan Waduk PLTA Koto Panjang Sebagai Upaya Pelestarian Fungsi Waduk yang Berkelanjutan. IPB. Bogor. in Indonesian.

Olasehinde. K.F., and A.A. Abeke. 2021. Limnological feature of Ikere Gorge Reservoir, Iseyin SouthWestern Nigeria: Physical-Chemical Parameters. Journal of Biodiversity and Environment Sciences (JBES). Vol 2 (6): 12 - 19 p.

Samuel, and Adiansyah, V. 2016. Kualitas air, status trofik dan potensi produksi ikan Danau Diatas, Sumatera Barat. Jurnal Penelitian Perikanan Indonesia, 22(2): 83-94. in Indonesian.

Siagian, M. 2010. Strategi Pengembangan Keramba Jaring Apung Berkelanjutan di Waduk PLTA Koto Panjang. Jurnal Perikanan dan Kelautan. Fakultas Perikanan dan Ilmu Kelautan Univ. Riau. 15 (2): 145-160. in Indonesian.

Simarmata, A.H., Siagian. M., and Sihotang. C. 2013. Vertical Profile of Oxygen in The Lacustrine and Transision Zone of Koto Panjang Reservoir, Riau Province. International Seminar of Fisheries and Marine $2^{\text {nd }}$. Proceeding of ISFM $2^{\text {nd. }}: 65-68 p$.

Simarmata, A.H., Siagian, M., and Sihotang, C. 2013. Pengelolaan Waduk Koto Panjang yang Berkelanjutan Berdasarkan Status Trofik dan Beban Perairan. Laporan Penelitian Unggulan Perguruan Tingggi. Lemlit. Univ. Riau Pekanbaru. in Indonesian.

Suprayogi, I., and Buchori. 2014. Kajian Sedimentasi Waduk PLTA Koto Panjang Dalam Upaya Melestarikan Kesinambungan Energi Listri Provinsi Riau. Jurnal Aplikasi Teknologi in Indonesian. Vol.2. No. 1. Hal: $111-116$. 